\title{
VOLTAGE TYPE Z-SOURCE CONVERTERS: OVERVIEW OF THE MAIN TOPOLOGIES
}

\author{
Euzeli C. dos Santos Jr., Fabrício Bradaschia, Marcelo C. Cavalcanti, Edison R. C. da Silva \\ emails: eudossan@iupui.edu, fabricio.bradaschia@ufpe.br, \\ marcelo.cavalcanti@ufpe.br, edison@dee.ufcg.edu.br
}

\begin{abstract}
This paper presents a review in terms of new configurations involving the $Z$-source converter concept. Since its first appearance, it is evident the importance assumed by the $Z$-source converter in the last years as a new topological structure with interesting features. As far as the authors' interest regarding the Z-source converter increases, new topologies have been developed for different applications. In spite of that, it is not observed in technical literature any reference furnishing a compilation of the main configurations related to this topic. The goal of this paper is to provide a complete range on the status of the $\mathrm{Z}$-source converter topologies to professionals and researchers interested in this topic. The configurations are grouped in five categories: $(i)$ twolevel configuration, $($ ii) multilevel configuration, (iii) $\mathbf{Z}$ source network improvement, $(i v)$ ac-ac conversion, and $(v)$ matrix converter. Based on the paper organization, it is possible to trace objectively the main developments in terms of new Z-source converter topologies.
\end{abstract}

Keywords - Z-Source Converter; Power Conversion; Power Electronics.

\section{INTRODUCTION}

Power electronics technology is present in a wide range of applications, including aerospace, transportation, industrial, commercial and residential applications. Such diversity can be explained due to the inherent characteristics observed in power electronics configurations, such as reduced size, high reliability, long lifetime, reduced cost and improvement of conversion performance. As described in [1], power electronics converters can be found in $i$ ) dc and ac regulated power supplies, $i i$ ) uninterruptible power supplies (UPS), $i i i$ ) electrochemical processes, $i v$ ) heating and lighting control, $v$ ) electronic welding, vi) power line static VAR compensators, vii) active harmonic filters, viii) high voltage dc (HVDC) systems, $i x)$ photovoltaic (PV) and fuel cell (FC) power conversion, $x$ ) solid state dc and ac circuit breakers, $x i$ ) motor drives, etc.

To deal with these very different applications, a large number of configurations have been established in technical literature. Indeed, since the beginning of the power electronics semiconductor age, it has been observed an increasing development in semiconductor devices, the main technology used to drive the power processors [2]. If we take a look at the semiconductor devices used in the first controlled rectifiers

Manuscript received on 16/07/2012. First revision on 21/08/2012. Accepted for publication on 14/11/2012 by recommendation of the Editor Henrique A. C. Braga.
[3] and compare it with the new technologies [4], it will be possible to figure out this development. Beyond the improvement related to power switches, it was also identified great activity in terms of circuit topology innovations.

The power electronics configurations can be grouped into different classifications, such as voltage-source and currentsource converters; converters with buck and boost capability; dc-ac, dc-dc, ac-dc and ac-ac converters, etc. For instance, the standard three-leg three-phase inverter observed in Figure 1(a) can be classified as a voltage-source, dc-ac buck converter. Other important converter, which is not included in the previous classification, was proposed by Peng $[5,6]$ and it has been called Z-source inverter. The voltage type Z-source inverter is depicted in Figure 1(b). Such converter presents some advantages as following: $i$ ) buck-boost operation with a single-stage converter, $i i$ ) it does not require dead-time protection, iii) the concept can be expanded for dc-dc, ac-dc and ac-ac converters as well as for current type converters.

Since its first appearance in 2002, the Z-source converter has been intensely explored by researchers worldwide, in a wide range of applications, such as photovoltaic [7], fuel cell [8-10], wind turbine $[11,12]$, uninterruptible power supply [13], adjustable speed drive [14], distributed power generation [15], hybrid electric vehicle [16].

Therefore, it is evident the importance assumed by the $\mathrm{Z}$-source converter in the last years, as a new topological structure that gathers interesting features. This is especially true regarding the large amount of new configurations conceived from its first version [5]. The immediate interest of the scientific community can be measured by the high and increasing number of publications, as depicted in Figure 2, which was obtained throughout a search in the IEEE website. Notice from this figure that the same behavior (positive derivative) is observed in both curves (conference and journal papers), meaning the importance assumed by this topic throughout the years. Despite that, it is not observed in the technical literature a reference which provides

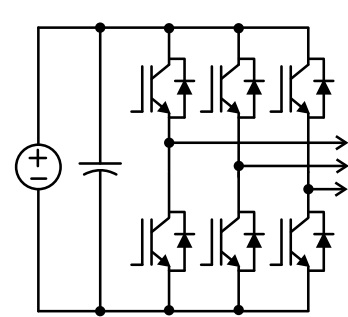

(a)

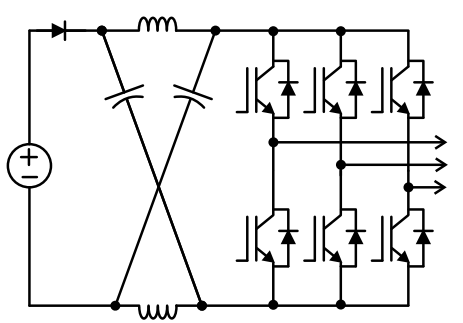

(b)
Fig. 1. (a) Conventional V-source converter. (b) Z-source converter $[5,6]$. 
a compilation of the main proposed topologies.

The objective of this paper is to survey and review the developments in terms of the Z-source converter configurations proposed in the technical literature, providing a complete range on the state of the art of $\mathrm{Z}$-source converter topologies to professional and researchers interested in this issue. As far as the attention of researchers related to the Zsource technology has increased since its first proposal $[5,6]$, the number of configurations related to this topic follows such demand. Nevertheless, it was noticed the lack of comparing the original Z-source converter with the new topologies. Then, the new configurations and their specific advantages are addressed and compared among themselves. In fact, several new Z-source topologies and their applications are illustrated. In spite of some existing Z-source configurations related to the $\mathrm{dc}-\mathrm{dc}$ conversion process, this paper will focus on converters which process ac voltage at input and/or output converter's sides. These topologies are grouped into five main categories, as observed in Figure 3.

Following this introduction, Section II shows a brief explanation of the principle of operation of the Z-source converter. Sections III and IV discuss the advances related to the two-level and Multilevel configurations, respectively; Section $\mathrm{V}$ presents the improvements of the $L C$ impedance, while Section VI brings the direct converters that employs the Z-source concept. Section VII deals with matrix converter configurations also regarding the concept of the Z-source converter. Finally, Section VIII brings the main conclusions of the paper.

\section{Z-SOURCE CONVERTER}

\section{A. Principle of Operation}

The Z-source converter can be considered as a new type of single-stage converter dealing with buck-boost energy conversion. This is possible by employing an impedance circuit between the converter and the primary energy source, as observed in Figure 1(b), and considering a particular PWM (Pulse Width Modulation) strategy that includes a shootthrough state. As described in $[5,6]$, the three-phase Zsource inverter bridge has nine permissible switching states,

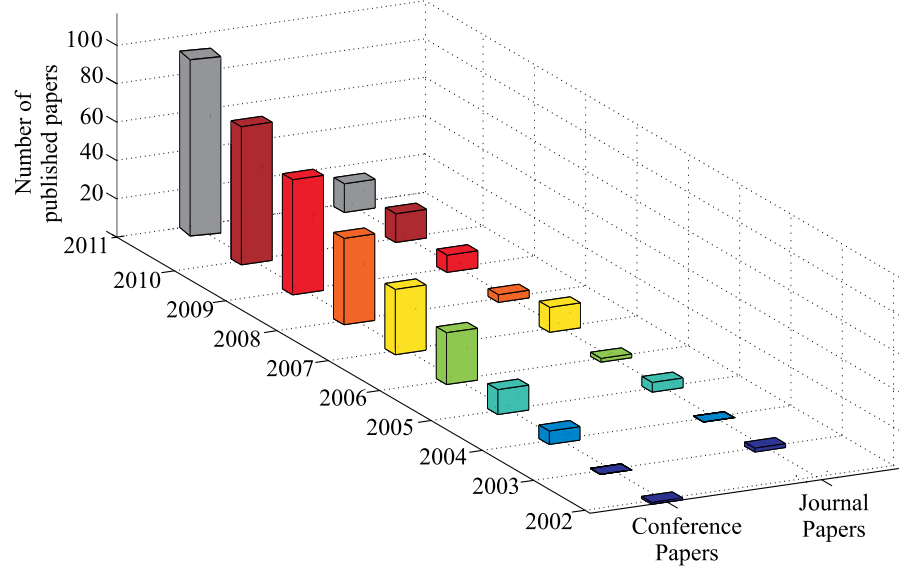

Fig. 2. Z-source converter related publications over the last nine years. differently from the traditional three-phase voltage-source inverter that has eight. This additional shoot-through state is obtained when the converter's input side is shorted through both upper and lower devices of any one phase leg, any two phase legs, or all three phase legs.

The PWM approach employed for the Z-source converter could be a simple carrier-based PWM strategy, as done in $[5,6]$, or any other method, as in [17-21]. Independently of the modulation strategy used, the inclusion of the shootthrough time interval in the switching period characterizes a necessary condition for boosting the Z-source converter. During the shoot-through, the energy from the capacitors are transferred to the inductors. Considering the same values for both inductors and for both capacitors in the Z-source LC impedance, it is possible to define the boost factor as being $B=1 /(1-2 D)$, where $D=T_{o} / T$ is the shoot-through duty ratio, $T_{o}$ is the time interval of shoot-through state, and $T$ is the switching period. The output voltage can be written as follows

$$
v_{a c}=M B \frac{V_{i n}}{2}
$$

where $M$ is the modulation index and $V_{i n}$ is the converter input voltage. From (1) it is evident that the output voltage can be stepped up or down by choosing appropriate values of $M$ and $B$

As mentioned before, all traditional PWM strategies can be used to control the $\mathrm{Z}$-source inverter, with the unique requirement of including the shoot-through time interval in each switching period. The sinusoidal reference voltage waveform is sometimes changed to a distorted waveform to guarantee some advantages related to harmonic distortion and reduction of switching losses, as described in [22]. As an example, Figure 4 presents the experimental results of the two non-sinusoidal reference voltages applied to the Z-source converter. In this figure, from top to bottom, the following waveforms are presented: distorted reference voltage, gating signal of one of the switches, three-phase load current, load phase voltage, and boost operation (input and capacitor voltages). Figure 4 (left) shows a set of the experimental results with THD improvements, while Figure 4 (right) shows

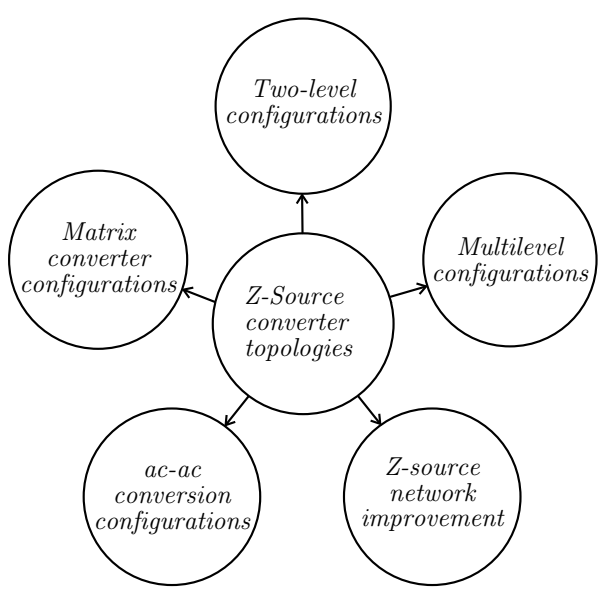

Fig. 3. Z-source converter configurations considered in this paper. 
a set of the experimental results with losses improvements. Then, even considering different strategies with different nonsinusoidal waveforms, it is possible to guarantee the Z-source converter boost operation properly.

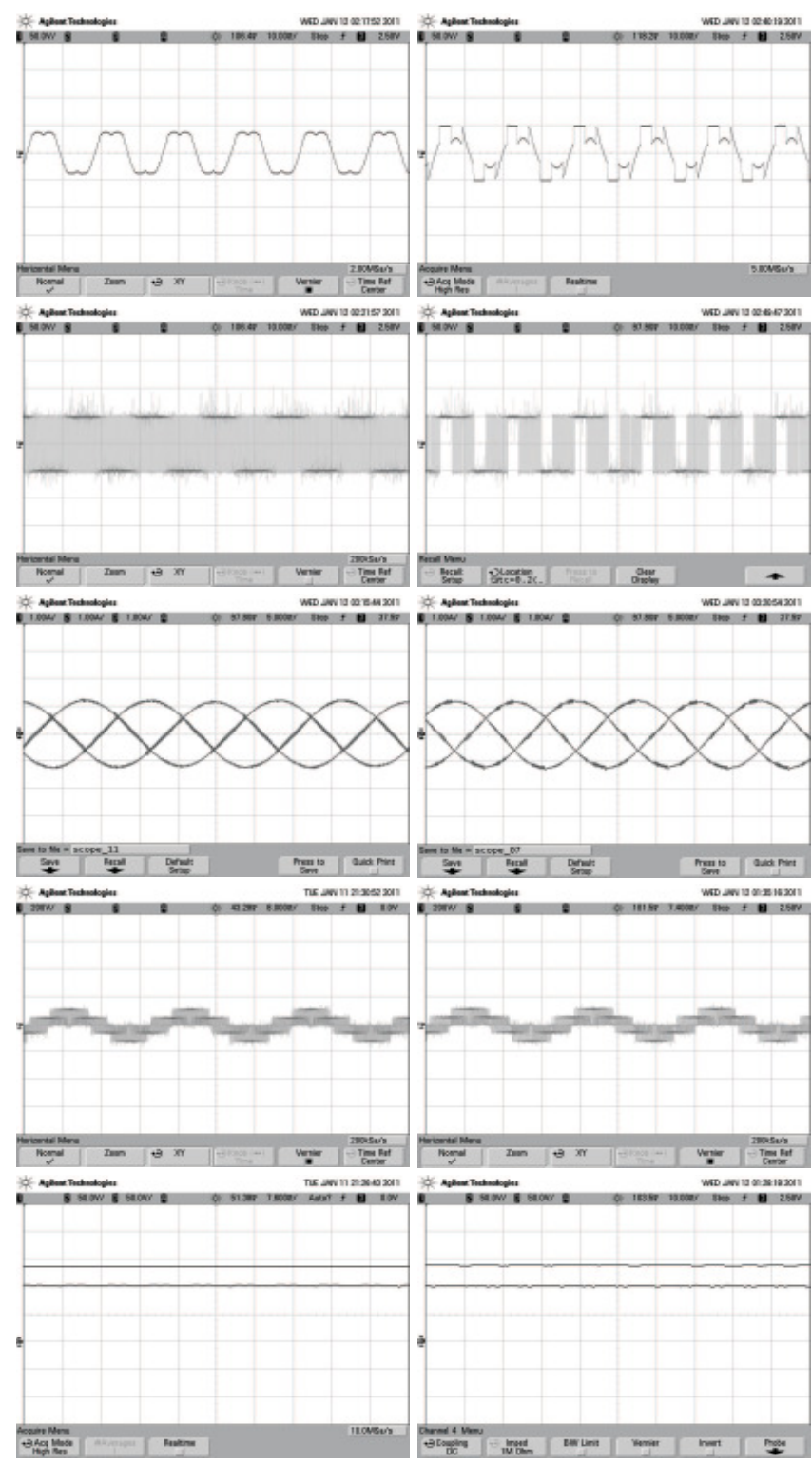

Fig. 4. Experimental results considering different PWM strategies applied to the Z-source converter.

\section{B. Control Modes}

Dynamic modelling of Z-source converter from different perspectives including different load and filter conditions are described in $[15,21,23,24]$. Based on these models, the converter input voltage $V_{i n}$ is controlled using a direct measurement [25], or through the measurement of the capacitor voltage [25], [26].

The paper presented in [27] proposes a closed-loop control of the dc-link voltage using both voltage mode and currentprogrammed-mode. Both modes are designed based on a proposed control strategy that uses estimation of $V_{i n}$ by using the measurements of the dc-source and capacitor voltages.
In case of the input disturbance rejection, it is verified that the voltage mode control gives better performance than the current-programmed-mode [27].

\section{TWO-LEVEL CONFIGURATIONS}

As mentioned before, many configurations were developed since the three-leg Z-source converter was conceived. In this section, configurations using the Z-source concept with twolevel converter are grouped.

The three-leg Z-source converter supplied by a single-phase utility grid was considered in [28] to fed a SPIM (SinglePhase Induction Machine), as shown in Figure 5. The same advantages guaranteed by the three-phase Z-source converter, are also observed in the circuit presented in [28], e.g., buckboost capability. Although this kind of motor is often used in fixed speed drives in home appliances, industrial tools or small power applications [29], there is also a requirement for SPIM in a variable motor speed operation [30]. The SPIM presents some drawbacks when compared to the three-phase induction machine, such as pulsating torque, higher price, size and volume.

On the other hand, the symmetrical two-phase motors can be considered as an interesting alternative for fractional horsepower variable-speed drives, due to the absence of pulsating torque produced by single-phase motors [31]. For instance, the two-phase motor can be used for heating, ventilating, and air-conditioning in hybrid electric vehicles applications [32]. The symmetrical two-phase motors supplied by converter employing a Z-source network was considered in [33]. Figure 6 shows the experimental waveforms for the symmetrical two-phase motor drive system with $\mathrm{Z}$-source converter.

The work presented in [34] proposes an alternative family of Z-source converter to be used for cases where implicit source filtering is a critical factor. Such converter was named as EZsource converter (Embedded Z-source), and it was considered in two- and three-level inverters versions. The two-level EZ-

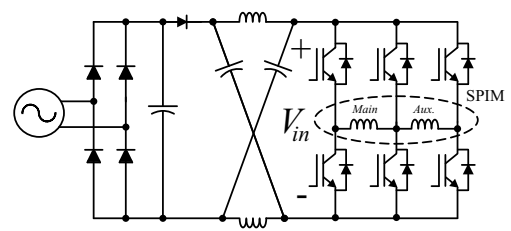

Fig. 5. Single-phase motor drive system with Z-source converter [28].

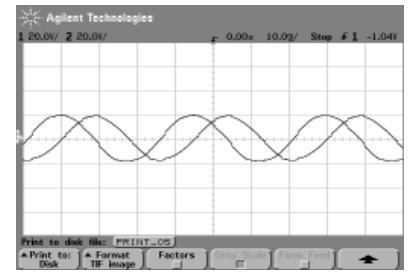

(a)

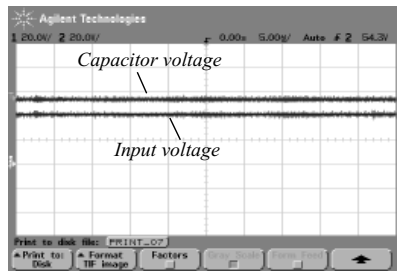

(b)
Fig. 6. Experimental results of the symmetrical two-phase motor drive system: (a) $d q$ currents and (b) capacitor and input voltages. 


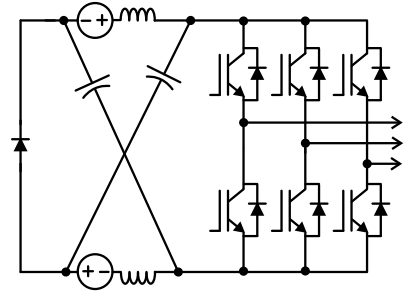

Fig. 7. Two-level embedded EZ-source inverter [34].

source converter is depicted in Figure 7, while the threelevel EZ-source converter is presented in the next section. Comparing this solution with the traditional one, the position of the dc sources and diode constitute the main structural difference between them. Despite such modifications, the voltage gain of the inverter is kept unchanged. An immediate disadvantage of the topology presented in Figure 7 is the need of two dc sources, instead of one in the conventional topology. The authors in [34] argue that it is not a major issue if this converter is used in PV or fuel-cell applications. In [35] it was presented an operational analysis and comparative evaluation of various embedded Z-source (EZ-source) inverters broadly classified as shunt or parallel embedded Z-source inverter.

In industrial applications where it is required to drive multiple electrical machines, the direct solution consists in replicating the standard configuration, i.e., replicating an input rectifier, a capacitor bank for the dc-bus, a voltage source inverter, an electrical machine and a microcomputer-based control system [36]. Considering the Z-source converters, the direct solution for drive multiple electrical machines consists in using a Z-source impedance for each inverter, which also represents a non-optimized solution in terms of system final cost. In this scenario the dc-ac nine-switch converter was first conceived as a voltage source inverter able to supply two threephase loads, as described in [37]. The main limitation of this converter is its smaller output voltage (when compared with two independent inverters), especially with different frequency operation. To solve this issue, the papers [38-40] present the same circuit as in [37] but with a single Z-source network in the converter's input side, as observed in Figure 8(a). Additionally, [38] introduces a space vector modulation for the proposed nine-switch-Z-source inverter. Figure 8(b) depicts the experimental results of Figure 8(a), where the voltage and current in one phase of a three-phase load connected in $\mathrm{Y}$ arrangement are presented. Noticed that, even considering this two-level configuration, the voltage waveform presents five levels due to load connection type.

Other important scenario also investigated by the authors in the technical literature is the case where it is necessary to establish a parallel connection of inverters. Parallel converters have been used to improve the power capability, reliability, efficiency and redundancy. Parallel converter techniques can be employed to improve the performance of active power filters [41-44], UPS [45, 46], fault tolerance of doubly fed induction generators [47], and three-phase drives [48].

Figure 9 shows the configuration proposed in [49]. Such topology presents the connection of two three-leg inverter bridges in a parallel way, which is supplied by a dc voltage source followed by X-shape $L C$ impedance. This work highlights the modulation and controllers design considering scenarios like interfacing fuel cells, solar cells, or variablespeed wind generators. The authors in [49] observed that when the interleaved carrier signals are used, the minimum switching method proposed in [20] could not longer be employed. As the shoot-through intervals of two inverters would not coincide all the time, this could lead to distortion in the volt-second average.

Table I presents a comparative analysis highlighting important figures of merit for the configurations in this section, such as boost capability $(B)$, passive elements (inductors and capacitors), number of isolated dc sources and amount of semiconductor devices, like diodes and switches. It is worth to mention that each power switch considered in the tables is the switch itself plus the freewheeling diode. Notice that all configurations have the same boost capability and an equal number of passive elements and diodes. On the other hand, the number of sources and power switches are different.

TABLE I

Comparative of Two-Level Converters

\begin{tabular}{cccccc}
\hline Configuration & B & L-C & Sources & Diodes & Switches \\
\hline Figure 5 & $\frac{1}{1-2 D}$ & $2-2$ & 1 & 1 & 6 \\
\hline Figure 7 & $\frac{1}{1-2 D}$ & $2-2$ & 2 & 1 & 6 \\
\hline Figure 8 & $\frac{1}{1-2 D}$ & $2-2$ & 1 & 1 & 9 \\
\hline Figure 9 & $\frac{1}{1-2 D}$ & $2-2$ & 1 & 1 & 12 \\
\hline
\end{tabular}

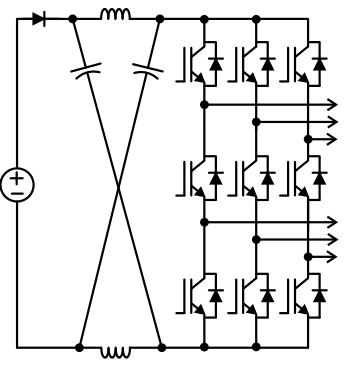

(a)

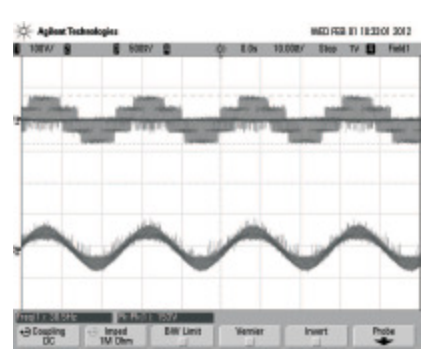

(b)
Fig. 8. Nine-switch-z-source inverter [38].

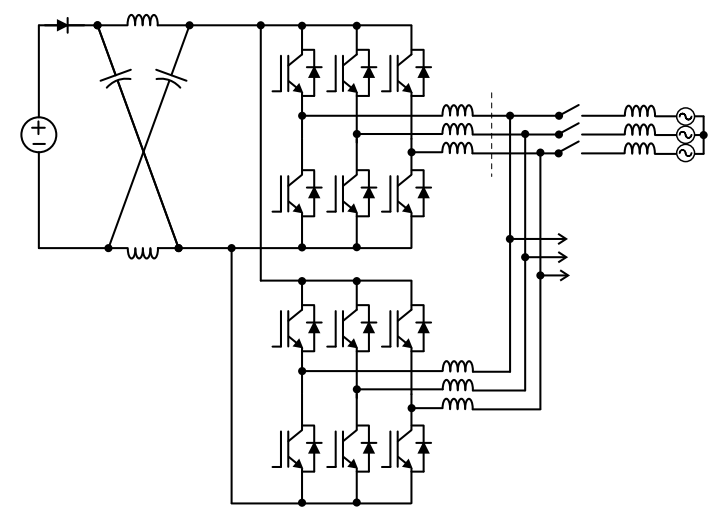

Fig. 9. Two paralleled three-leg Z-source inverters [49]. 


\section{MULTILEVEL CONFIGURATIONS}

Multilevel converters were first conceived for high-voltage and high-power applications beginning with the NPC (Neutral Point Clamped) inverter proposed in [50]. Since then, many configurations have been proposed, as in [51] and [52], to establish the highly desirable characteristics for high-power applications [53], such as reduced waveform distortion and low blocking voltage in the switching devices. The three principal configurations are NPC, flying capacitor and cascade multilevel inverters $[54,55]$.

More recently, the multilevel converters has found acceptance in low power applications, especially in photovoltaic, since it is possible to generate high-quality voltage waveforms with power semiconductor switches operating at frequencies near the fundamental [56] and with no restrictions in the number of input dc sources [57]. Even considering just one dc voltage source available, it is possible to use converters with different dc-link voltages employing additional circuitry [58].

Multilevel configurations using the concept of the Z-source inverters (X-shaped $L C$ impedance network inserted between primary energy of source and the inverter bridge) could be considered as a natural tendency, and it was first presented in $[18,59]$, as can be seen in Figure 10. Figure 11 shows the experimental results of the circuit proposed in Figure 10.

As in the conventional NPC inverter, the circuit presented in Figure 10 brings the possibility of operating with commonmode voltage elimination. Additionally, with the use of two impedance networks, the boost operation is guaranteed without shooting through the inverter full de link. This paper also proposes a modulation strategy with minimized harmonic distortion and device commutations per half carrier cycle.

The authors themselves express clearly in [60] that there is a possible economical problem related to this solution, directly related to the number of $L C$ elements needed in this topology, although it is theoretically feasible.

After the employment of the Z-source concept in NPC three-phase three-level configurations, the same group of researchers proposed in [17] a dual Z-source inverter topology, implemented through cascading two Z-source inverters with a three-phase transformer. Such converter is conceived in two versions: with a single dc source and two isolated sources, as observed in Figure 12. Notice that the proposed dual inverter supports bidirectional power conversion, since the bidirectional switches are used instead of diodes.

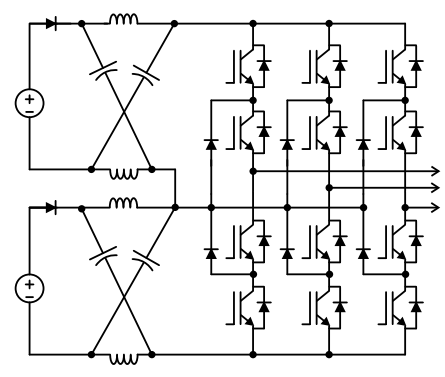

Fig. 10. Z-source NPC inverter [18].
Following the same research field, [61] proposed an optimization of the converter presented in Figure 10 with reduced number of passive elements, where a single $L C$ impedance is used in a conventional three-level NPC configuration and in a dc-link cascaded inverter, as seen in Figures 13(a) and 13(b), respectively.

Soon after, the authors in [62] propose the dc-link-cascaded Z-source inverter, as observed in Figure 14, bringing back the use of two isolated power sources. The dc sources are connected through two $L C$ impedance networks to a dc-linkcascaded inverter. In the same paper, the authors propose two other configurations with a three-phase transformer connected between the output inverter side and the load, and with two and one $L C$ impedance networks. Those configurations are omitted in this paper.

The multilevel Z-source configuration using a single $L C$ impedance, presented in [60], was employed in [63]. Such configuration is depicted in Figure 15.

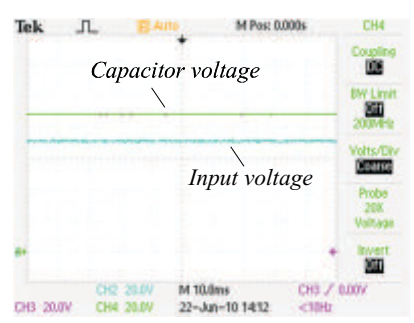

(a)

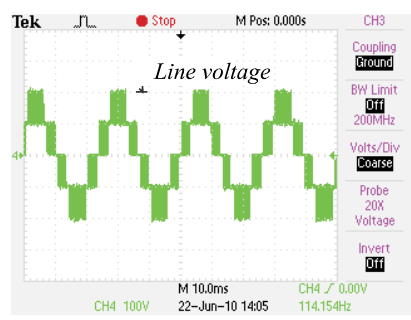

(b)
Fig. 11. Experimental results of the Z-source NPC inverter.

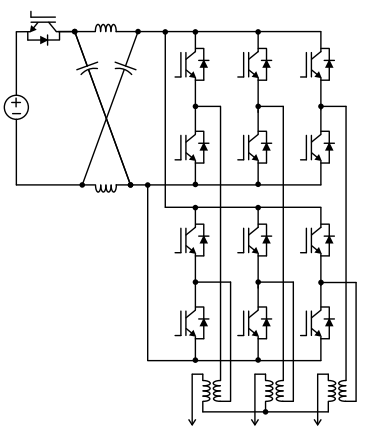

(a)

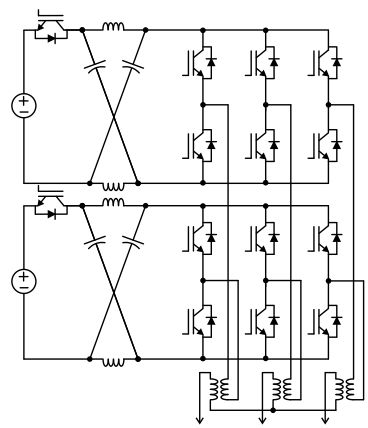

(b)
Fig. 12. Dual Z-source inverter [17] with (a) a single dc source and (b) two isolated dc sources.

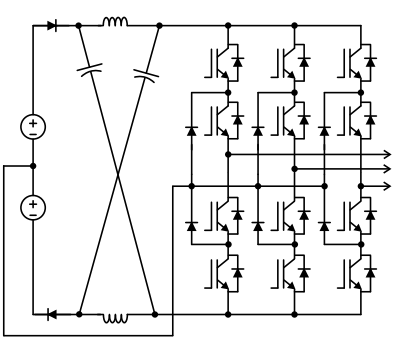

(a)

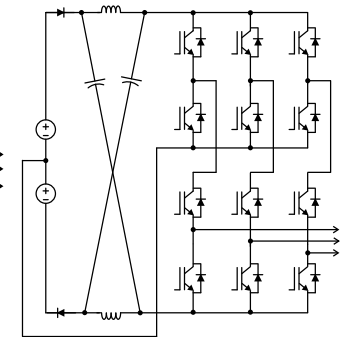

(b)
Fig. 13. Multilevel configurations with a single impedance network between the dc source and the inverter [61]. 


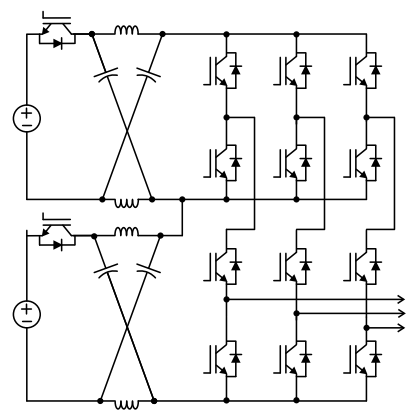

Fig. 14. Dc-link-cascaded Z-source inverter with two $L C$ impedance networks [62].

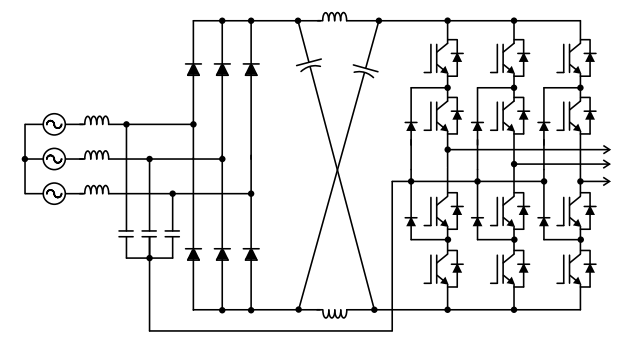

Fig. 15. Z-source multilevel inverter with one $L C$ impedance [63].

The three-level version of the converter studied in [34] (see Figure 7) is shown in Figure 16, and it presents the same characteristics of the two-level converter version in [34].

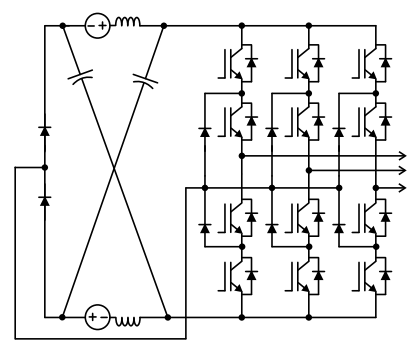

Fig. 16. Three-level embedded EZ-source inverter [34].

The authors in [64] proposes a five-level Z-source diodeclamped inverter designed with two intermediate Z-source networks connected between the dc input sources and rear-end inverter circuitry, as observed in Figure 17 for one leg.

The single-phase multilevel converter with series connection of the Z-source H-bridge configurations (Figure 18) is conceived in [65] for dynamic voltage restorer applications.

Table II presents a comparative analysis for the configurations in this section. Some topologies could present different boost factors, depending on the modulation technique applied.

\section{IMPROVEMENT OF THE $L C$ IMPEDANCE NETWORK}

After showing the advances in two- and three-level configurations, all related to the converter itself (number and position of the legs and switches), this section presents the progress related to $L C$ impedance arrangements. Indeed, all

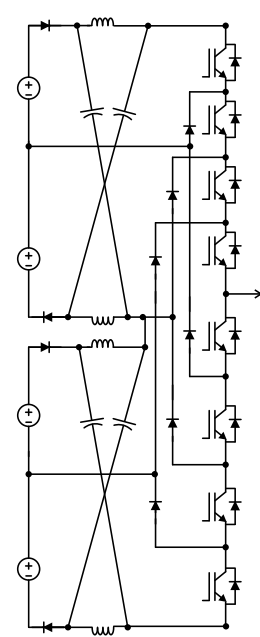

Fig. 17. Five-level Z-source diode-clamped inverter [64].

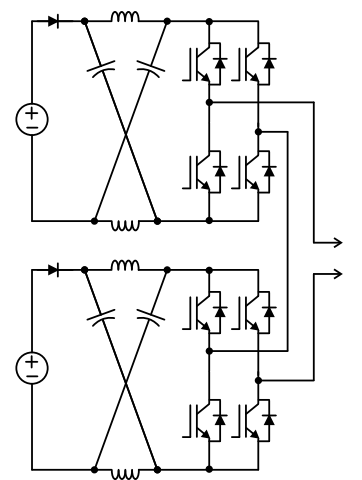

Fig. 18. Single-phase multilevel inverter based on Z-source concept [65].

topologies presented in the last two sections use the same $L C$ elements and connections as conceived in $[5,6]$, i.e., the $L C$ elements in a X-shaped connection.

Many authors have proposed new connection arrangement for the passive elements (and diode) to address specific characteristics, such as $(i)$ expanded output voltage range (larger gain), (ii) lower component ratings, (iii) reduced input source stress, and (iv) reduced component count. Such characteristics are important because shorter shoot-through duration means a larger modulation index for the same boost capability requirement, leading to a improvement in the output waveform quality. In spite of these new impedance arrangements, it is worth to mention that the same philosophy of the traditional Z-source converter is maintained, i.e., the concept of single-stage conversion including a shoot-through to guarantee its boost operation.

Most of the papers try to overcome the drawbacks of voltage type Z-source converter, i.e., discontinuity of the input current and high voltage operation of the capacitors in boost mode. As an attempt to improve such features, four new configurations called quasi-Z-source inverters, in its abbreviated form qZSIs, were developed. Two of the converters proposed in [66] are depicted in Figure 19. Since this paper highlights the advantages regarding the voltage type Z-source converters, the 
TABLE II

Comparative of Multilevel Converters

\begin{tabular}{cccccc}
\hline Configuration & B & L-C & Sources & Diodes & Switches \\
\hline Figure 10 & $\frac{1}{1-2 D} / \frac{1}{1-D}$ & $4-4$ & 2 & 8 & 12 \\
\hline Figure 12(a) & $\frac{1}{1-2 D}$ & $2-2$ & 1 & 0 & 13 \\
\hline Figure 12(b) & $\frac{1}{1-2 D}$ & $4-4$ & 2 & 0 & 14 \\
\hline Figure 13(a) & $\frac{1}{1-2 D}$ & $2-2$ & 2 & 8 & 12 \\
\hline Figure 13(b) & $\frac{1}{1-2 D}$ & $2-2$ & 2 & 2 & 12 \\
\hline Figure 14 & $\frac{1}{1-D}$ & $4-4$ & 2 & 0 & 14 \\
\hline Figure 15 & $\frac{1}{1-2 D}$ & $2-2$ & 1 & 6 & 12 \\
\hline Figure 16 & $\frac{1}{1-2 D} / \frac{1}{1-D}$ & $2-2$ & 2 & 8 & 12 \\
\hline Figure 17 & $\frac{1}{1-2 D}$ & $4-4$ & 2 & 2 & 8 \\
\hline
\end{tabular}

current type qZSI versions, proposed in the same reference, have been omitted.

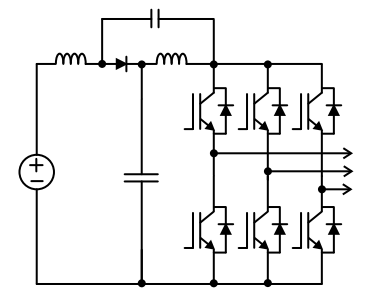

(a)

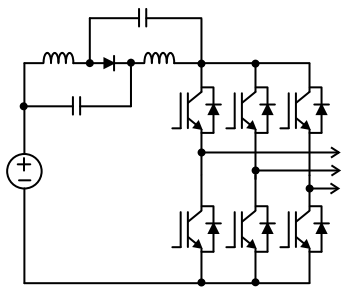

(b)
Fig. 19. Voltage type qZSI converter [66] with: (a) continuous input current and (b) discontinuous input current.

The work presented in [67] brings the concept of switched inductor (SL), originally employed in dc-dc converters, to be used in Z-source inverter. Figure 20(a) shows the converter proposed in [67]. The main characteristic of this configuration is the voltage boost increase, compared to the traditional Z-source converter for the same shoot-through time interval. Following the same philosophy, [68] presents a new impedance network, based on two Tapped-Inductor (TL) cells, for implementing TL Z-source inverter, as observed in Figure 20(b). Such converter produces a much larger voltage boost at high modulation indexes, when compared to the classical Z-source inverter.

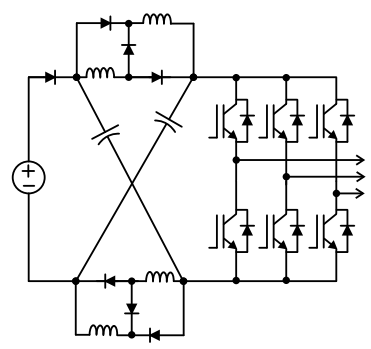

(a)

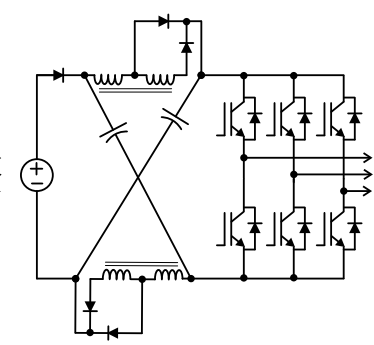

(b)
Fig. 20. High voltage boost Z-source topologies: (a) switched inductor type [67] and (b) tapped-inductor type [68].
The time available to generate the shoot-through, inherent of the Z-source converter, is lower as the modulation index increases. The limitation related to the interdependency between the shoot-through time interval and modulation the index was considered in [69]. A new family of Z-source converters with extended-boost capability were considered in [69]. The configurations proposed in [69] were called as diode-assisted extended-boost qZSI, which are subdivided as continuous-current and discontinuous-current topologies. Figure 21(a) shows the continuous-current topology and it can be extended to have a very high boost by cascading more stages, as shown in Figure 21(b). Such converter presents three operating states, as well as the conventional Z-source topology. Comparing with the traditional Z-source converter, the boost factor of the circuit depicted in Figure 21(a) has increased by a factor of $1 /(1-D)$.

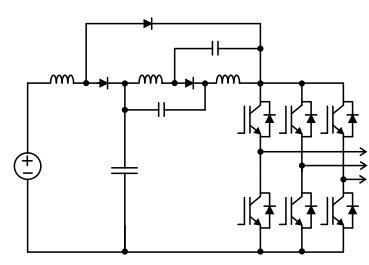

(a)

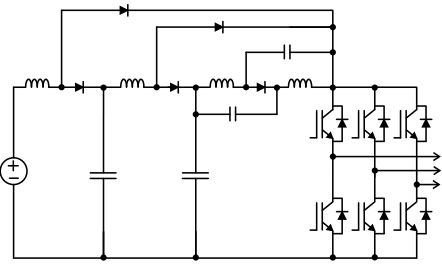

(b)
Fig. 21. Diode-assisted extended-boost continuous-current qZSI [69]: (a) first extension. (b) second extension.

The diode-assisted extended-boost discontinuous-current qZSI [70] has the same boost factor as that of the continuous current topology, but the capacitors are subjected to smaller voltage stress. The boost factor of the second extension for both continuous- and discontinuous-current qZSI are given by $B=1 /[(1-2 D)(1-D)(1-D)]$.

In the same paper [69], the authors proposed a capacitorassisted extended-boost qZSI (Figure 22). As done for the previous configurations (Figure 21) the converter's three operating states are simplified into shoot-through and nonshoot-through states. The boost factor for those topologies is given by $B=1 /(1-4 D)$.

The evident disadvantage of the proposed circuits in [69], when compared to traditional Z-source converter, is the high number of passive elements by using additional inductors, capacitors, and diodes. The reduction in effective voltage gain when the shoot-through or the load current increases is directly affected by the non-ideal behavior of those elements, especially by the parasitic resistances of inductions.

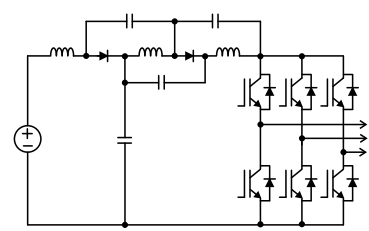

(a)

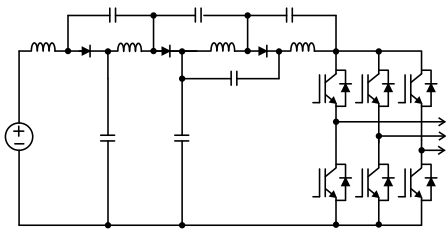

(b)
Fig. 22. Capacitor-Assisted Extended-Boost qZSI Topologies [69]: (a) first extension. (b) second extension. 


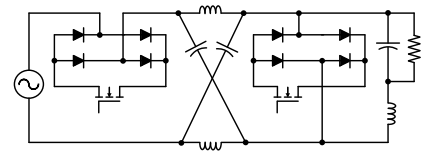

(a)

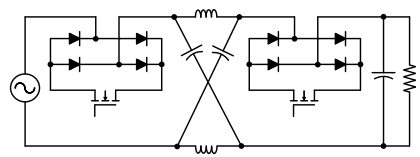

(b)
Fig. 23. Single-phase Z-source ac-ac converter [70]: (a) voltage-fed and (b) current-fed version.

Table III presents a comparative analysis for the configurations in this section. It is assumed that the two tapped-inductor cells in the TL Z-source inverter of the Figure 19(b) present the same number of turns (unitary turn ratios).

\section{TABLE III}

Comparative of the Converters

\begin{tabular}{cccccc}
\hline Configuration & B & L-C & Sources & Diodes & Switches \\
\hline Figure 18 & $\frac{1}{1-2 D}$ & $2-2$ & 1 & 1 & 6 \\
\hline Figure 19(a) & $\frac{1+D}{1-3 D}$ & $4-2$ & 1 & 7 & 6 \\
\hline Figure 19(b) & $\frac{1+D}{1-3 D}$ & $4-2$ & 1 & 5 & 6 \\
\hline Figure 20(a) & $\frac{1}{(1-2 D)(1-D)}$ & $3-3$ & 1 & 3 & 6 \\
\hline Figure 20(b) & $\frac{1}{(1-2 D)(1-D)^{2}}$ & $4-4$ & 1 & 5 & 6 \\
\hline Figure 21(a) & $\frac{1}{1-3 D}$ & $3-4$ & 1 & 2 & 6 \\
\hline Figure 21(b) & $\frac{1}{1-4 D}$ & $4-6$ & 1 & 3 & 6 \\
\hline
\end{tabular}

\section{AC-AC CONVERSION CONFIGURATIONS}

Single-phase ac-ac converters with a reduced number of semiconductor devices were presented in [70] in two versions: voltage-fed and current-fed Z-source converters, as observed in Figure 23(a) and Figure 23(b), respectively. In spite of reducing the number of power switches dramatically, the proposed circuits employ a PWM control with continuously variable turns ratio. The main characteristics of these circuits are: $(i)$ output ac voltage with buck-boost capability, (ii) reversing or maintaining phase angle, (iii) reduced in-rush and harmonic current, and $(i v)$ improved reliability. In terms of application, these configurations can be employed where only voltage regulation is needed, as in ac-ac line conditioner.

In [71] it was proposed a type of quasi-Z-source converter applied to ac-ac power conversion, as depicted in Figure 24. Besides the advantages of the traditional single-phase Zsource ac-ac converter, the converter proposed in [71] brings as advantages: $(i)$ the input voltage and output voltage shares the same ground and ( $i i)$ the converter operates in CCM with special features, such as reduced in-rush, harmonic current, and improved power factor.

The converters presented in Figure 25 were proposed in [72]. Furthermore, this work proposes safe commutation strategies, which are implemented without snubber circuit. Following the same philosophy, it has been considered in the same paper the single-phase version of the Z-source ac-ac converters, which is not shown in this paper.

Table IV presents a comparative analysis for the configurations in this section.
TABLE IV

Comparative of AC-AC Converters

\begin{tabular}{cccccc}
\hline Configuration & B & L-C & Sources & Diodes & Switches \\
\hline Figure 22(a) & $\frac{1-D}{1-2 D}$ & $3-3$ & 1 & 6 & 2 \\
\hline Figure 22(b) & $\frac{1-2 D}{1-D}$ & $2-3$ & 1 & 6 & 2 \\
\hline Figure 23 & $\frac{1-D}{1-2 D}$ & $3-3$ & 1 & 0 & 4 \\
\hline Figure 24 & $\frac{D}{\sqrt{3 D^{2}-3 D+1}}$ & $6-6$ & 3 & 0 & 6 \\
\hline
\end{tabular}

\section{MATRIX CONVERTER CONFIGURATIONS}

The main advantage of matrix converters (MC) is to perform ac-ac power conversion without a bulky dc-link capacitor. Moreover, other desirable features such as bidirectional power flow, controllable input power factor and minimal energy storage requirements made this topology a subject of intense research for the last three decades [73]. Traditional MCs are implemented with two different topologies: the single-stage direct matrix converter (DMC), shown in Figure 26(a), and the two-stage indirect matrix converter (IMC), shown in Figure 26(b) [73]. Unfortunately, the MC did not gain the expected spread application in industry due to its two major drawbacks: the reduced voltage transfer ratio of 0.866 and the complex and unsafe multistep commutation of its controlled bidirectional switches [74].

The paper presented in [75] furnishes the three main constraints observed in the variable-voltage-variablefrequency application, i.e., a) the amplitude of the ac voltage must be lower than the dc voltage; $b$ ) in case of the rectification operation, it is necessary the indirect control of both dc voltage and ac phase current angle; and c) ac terminal voltage are highly sensitive to the dc source voltage. To overcome these inherent difficulties the authors in [75] suggests a Z-source converter configuration which deals with specific advantages of the bidirectional switches of the matrix converter. The configuration proposed in [75] is named MZC (matrix-Z-source converter) in [76] and it is depicted in Figure 27. MZC consists of four parts, which are the switch network comprising six four-quadrant switches; Z-source network with a block switch comprising four passive components (two capacitors and two inductors) and one unidirectional power switch using a diode in series with a MOSFET; low-pass filter for three-phase ac terminals (not shown in Figure 27); and low-pass filter for de terminals (not shown in Figure 27). The quadrant operation of the MZC, its control, its steady-state performance and experimental verification were investigated in [76].

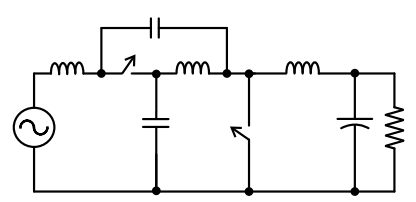

Fig. 24. Single-phase quasi-Z-source ac-ac converter topology with continuous input current and sharing the ground [71]. 


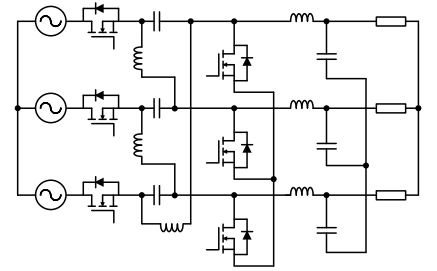

(a)

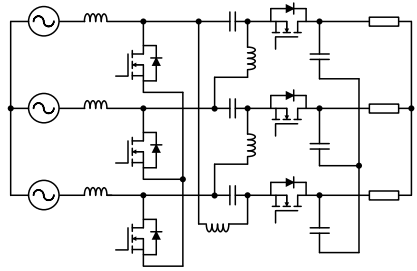

(b)
Fig. 25. Three-phase Z-source ac-ac converters [72]: (a) voltage-fed. (b) current-fed.

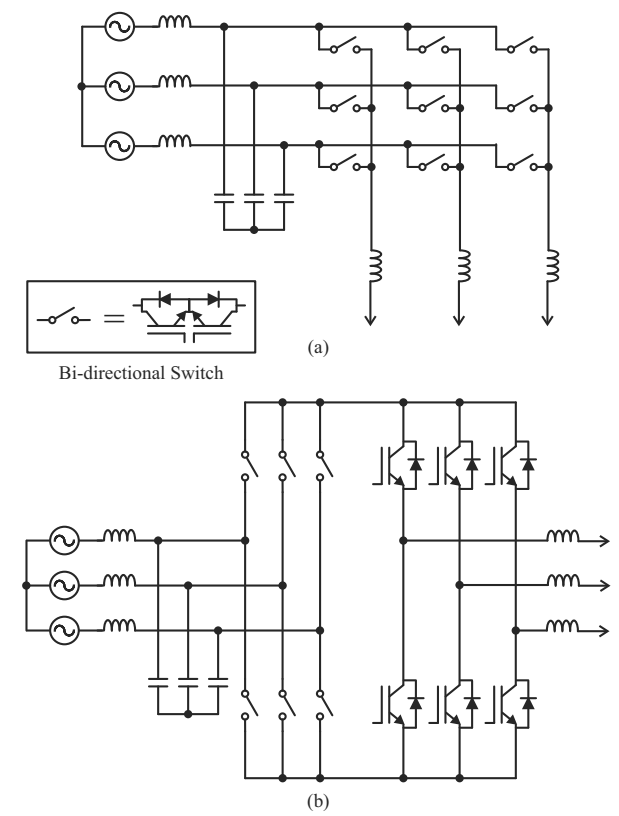

Fig. 26. Matrix converter topologies [73]: (a) single-stage DMC; (b) two-stage IMC.

Two discontinuous PWM strategies for dc-ac threephase voltage-source-inversion and three-phase ac-dc voltagesource-rectification were proposed in [77] for the MZC operation. They are based on the general space vector modulation approach derived from matrix converter. The general space vector modulation is a technique with arbitrary zero placement. Its algorithm requires neither hypothetical dc rails nor assumption of unity power factor at topology input.

The analytical calculation of conduction and switching losses for the MZC was presented in [78]. The loss models were constructed taking into account the modulation strategy while the calculation of semiconductor losses are based on switching devices' parameters verified experimentally. A comparison with VSI showed that in the start-up operation the MZC has less total loss than the VSI converter in certain range of modulation index. While in the generating operation mode, the MZC has less total loss than the VSI in almost the full range of modulation index.

Disturbance in ac source or fault in load current can cause serious over-voltage in MZC [79]. A common over-voltage protection uses a diode-capacitor configuration with 12 fast recovery diodes, one storage capacitor and one discharge resistor. The diode-capacitor configuration may be directly

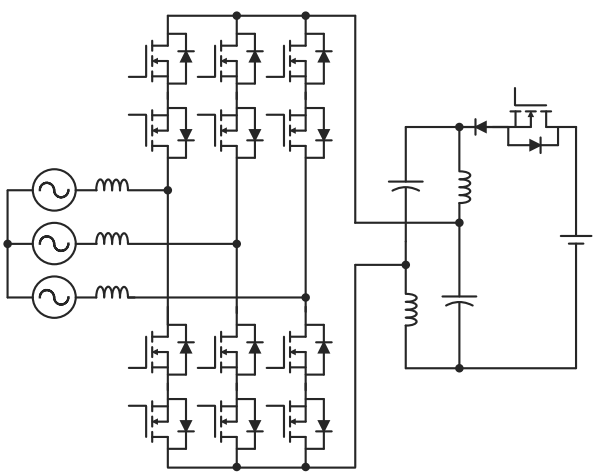

Fig. 27. Matrix-Z-source converter [76].
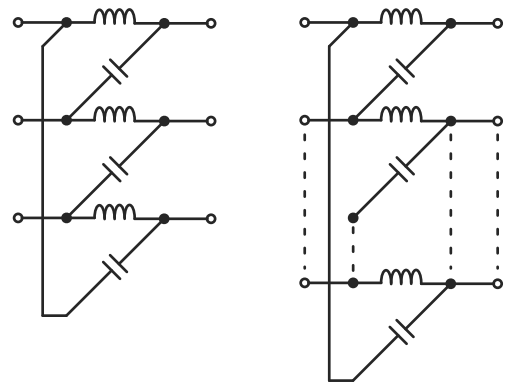

Fig. 28. Three- and multi-phase Z-source networks [80].

used for MZC but an extra circuit brake has to be employed. The power zener bidirectional diode, proposed in [79], provides high voltage protection for MZC by fast clamping without the aging problems found in varistor solution.

Recent works extend the Z-source converter concept and present several Z-source networks for different power conversion purposes, including three- and multi-phase Zsource networks (Figure 28) [80], [81].

The direct application of three-phase Z-source networks is in voltage-fed and current-fed MCs, as can be seen in Figure 29(a) and 29(b), respectively. Both topologies, named voltage-fed and current-fed simplified Z-source MC (VF-SZS and CF-SZS MC), can buck and boost the voltage to the desired level and require only simple, safe and single-step commutation strategies $[81,82]$. With the proper control of the shoot-through time interval and applying a specific switching sequence, it is possible to achieve unity voltage transfer ratio and reduce harmonic distortion of the output waveforms [74].

Other possible application is use the traditional Z-source network in the two-stage sparse $\mathrm{MC}$, which presents a reduced number of power switches [73]. This topology, named Zsource sparse matrix converter (ZSMC - Figure 30), is formed by a bidirectional sparse rectifier connected to a bidirectional Z-source inverter and overcomes the inherent drawback of the low transfer ratio of traditional MCs [73]. Through a proper control, the ZSMC topology can synthetize balanced output voltages even with abnormal input voltage conditions [83] and provides ride-through capability during voltage sags, without any additional hardware [84], maintaining all known advantages of traditional MCs.

In order to reduce even more the number of switches, a Z-source indirect matrix converter (ZSIMC - Figure 31), 
formed by a unidirectional sparse rectifier connected to a unidirectional Z-source inverter, was proposed [85]. Despite of being unidirectional, the ZSIMC presents the other advantages of the ZSMC topology, using only 9 switches (less than a traditional back-to-back converter), becoming an alternative for ac-ac buck-boost energy conversion [85]. A three-level adaptation of the ZSIMC, using a unidirectional sparse rectifier connected to a NPC Z-source inverter (Figure 32 ), presents the same characteristics of its predecessor with the advantage of higher buck-boost factor, higher voltage stress capability and reduced output voltage distortion [86].

A comparative analysis for the configurations in this section is presented in Table $\mathrm{V}$.

\section{CONCLUSIONS}

This paper presented a comprehensive review regarding the Z-source converters, all associated with those ones that process ac voltage. Following what is observed in the technical literature, this paper was organized and sorted in five categories: ( $i$ ) two-level configurations, $(i i)$ multilevel configurations, (iii) Z-source network improvement, (iv)
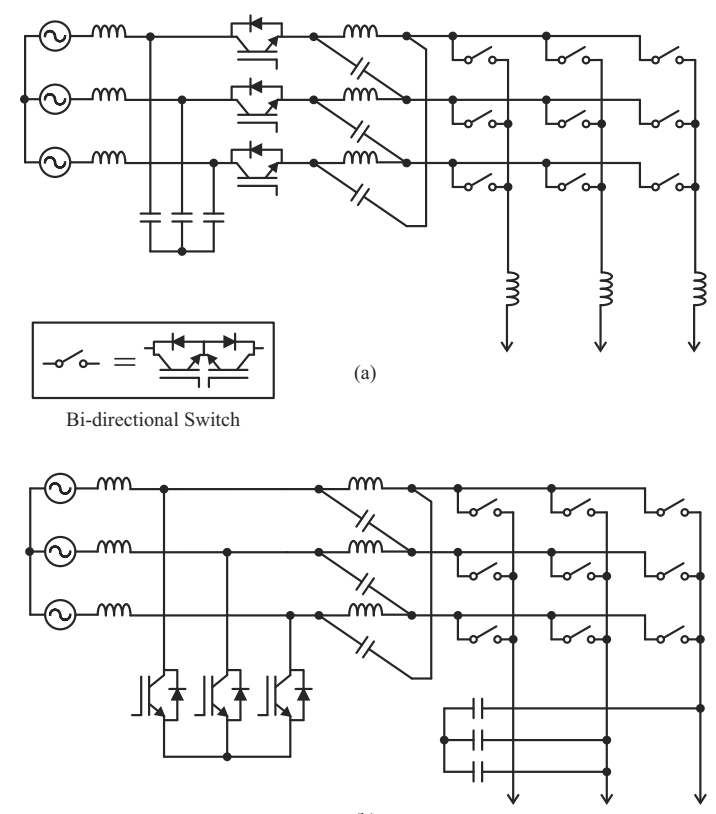

(b)

Fig. 29. Three-phase direct matrix converter topologies: (a) VF-SZS $\mathrm{MC}$; (b) CF-SZS MC [82].

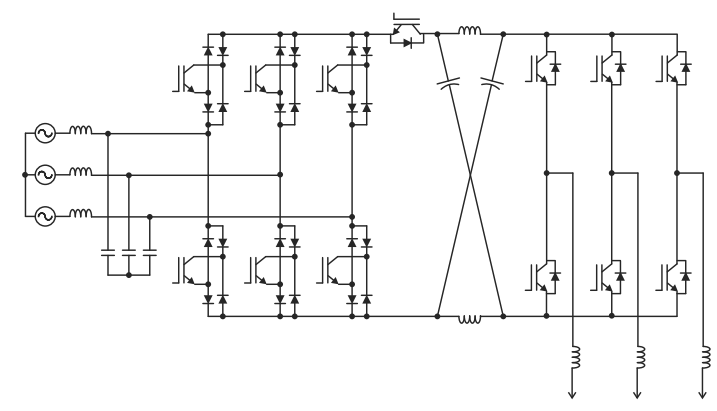

Fig. 30. ZSMC topology [83].

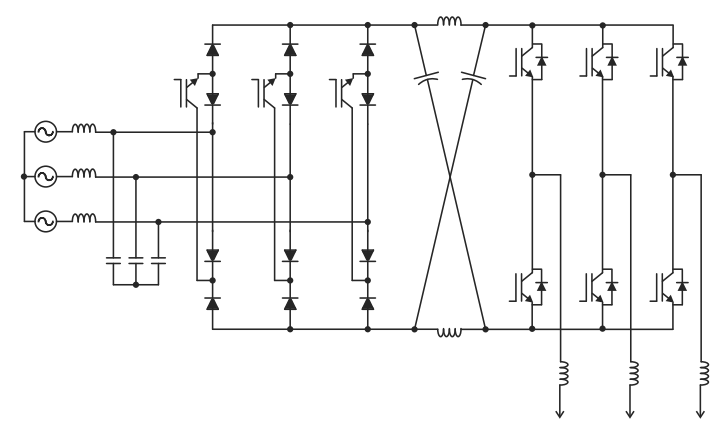

Fig. 31. Two-level ZSIMC topology [85].

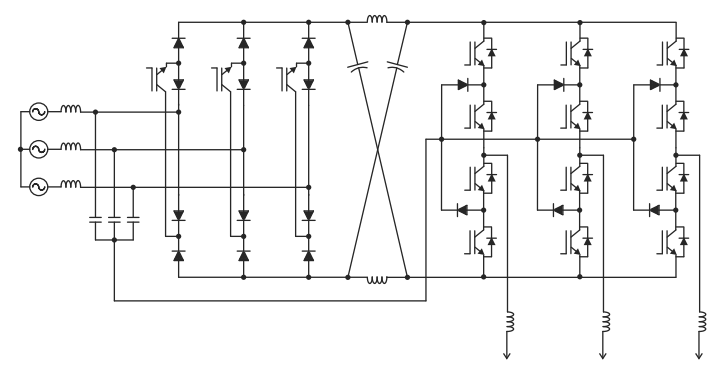

Fig. 32. Three-level ZSIMC topology [86].

TABLE V

Comparative of Matrix Converter Configurations

\begin{tabular}{cccccc}
\hline Configuration & B & L-C & Sources & Diodes & Switches \\
\hline Figure 26 & $\frac{1}{1-2 D}$ & $2-2$ & 1 & 1 & 13 \\
\hline Figure 28 & $\frac{1-D}{\sqrt{3 D^{2}-3 D+1}}$ & $6-6$ & 3 & 0 & 21 \\
\hline Figure 29 & $\frac{1}{1-2 D}$ & $5-5$ & 3 & 18 & 13 \\
\hline Figure 30 & $\frac{1}{1-2 D}$ & $5-5$ & 3 & 9 & 9 \\
\hline Figure 31 & $\frac{1}{1-2 D}$ & $5-5$ & 3 & 15 & 15 \\
\hline
\end{tabular}

ac-ac conversion configurations and $(v)$ matrix converter configurations.

It is worth to mention that many of the configurations considered were just the application of the ideas already established with the new Z-source concept, e.g., series and parallel connection of Z-source converters. On the other hand, important advancements have been observed considering the improvements of the $L C$ impedance, in spite of lack comparison in terms of efficiency.

The main conclusions are given as follows: $(a)$ z-source converter can be considered a versatile concept which means that it can be applied in a large variety of applications, (b) in spite of considering the large amount of configurations, it is not evident the influence of the important aspects, such as lifespan of the semiconductor and passive elements (capacitor mainly) due to shoot-through state, and $(c)$ there exist a perspective of exploring this kind of technology in renewable energy systems, mainly because the single-stage conversion possibility. It is clear that the development of topologies like the Z-source converter, with high potential application in renewable energy systems, constitutes an important topic for continuous research activities, since the discussion about the 
future of energy supply is crucial for sustainability and to solve problems involving fossil fuels.

\section{REFERENCES}

[1] B. Bose, "Power electronics and motor drives recent progress and perspective," Industrial Electronics, IEEE Transactions on, vol. 56, no. 2, pp. 581 -588, feb. 2009.

[2] F. Blaabjerg, A. Consoli, J. Ferreira, and J. van Wyk, "The future of electronic power processing and conversion," Industry Applications, IEEE Transactions on, vol. 41, no. 1, pp. $3-8$, jan.-feb. 2005.

[3] F. W. Gutzwiller, "Thyristors and rectifier diodes - the semiconductor workhorses," Spectrum, IEEE, vol. 4, no. 8, pp. $102-111$, aug. 1967.

[4] A. Elasser, M. Kheraluwala, M. Ghezzo, R. Steigerwald, N. Evers, J. Kretchmer, and T. Chow, "A comparative evaluation of new silicon carbide diodes and state-ofthe-art silicon diodes for power electronic applications," Industry Applications, IEEE Transactions on, vol. 39, no. 4, pp. 915 - 921, july-aug. 2003.

[5] F. Peng, "Z-source inverter," in Industry Applications Conference, 2002. 37th IAS Annual Meeting. Conference Record of the, vol. 2, 2002, pp. 775 - 781 vol.2.

[6] F. Z. Peng, "Z-source inverter," Industry Applications, IEEE Transactions on, vol. 39, no. 2, pp. 504 - 510, mar/apr 2003.

[7] Y. Huang, M. Shen, F. Peng, and J. Wang, "Z-source inverter for residential photovoltaic systems," Power Electronics, IEEE Transactions on, vol. 21, no. 6, pp. 1776 -1782, nov. 2006.

[8] J.-W. Jung and A. Keyhani, "Control of a fuel cell based z-source converter," Energy Conversion, IEEE Transactions on, vol. 22, no. 2, pp. 467 -476, june 2007.

[9] M. Mohr, W. Franke, B. Wittig, and F. Fuchs, "Converter systems for fuel cells in the medium power range - a comparative study," Industrial Electronics, IEEE Transactions on, vol. 57, no. 6, pp. $2024-2032$, june 2010.

[10] M. Shen, A. Joseph, J. Wang, F. Peng, and D. Adams, "Comparison of traditional inverters and $\mathrm{z}$-source inverter for fuel cell vehicles," Power Electronics, IEEE Transactions on, vol. 22, no. 4, pp. 1453 -1463, july 2007.

[11] S. Zhang, K.-J. Tseng, D. Vilathgamuwa, T. Nguyen, and X.-Y. Wang, "Design of a robust grid interface system for pmsg-based wind turbine generators," Industrial Electronics, IEEE Transactions on, vol. 58, no. 1, pp. 316 -328 , jan. 2011.

[12] S. Dehghan, M. Mohamadian, and A. Varjani, "A new variable-speed wind energy conversion system using permanent-magnet synchronous generator and z-source inverter," Energy Conversion, IEEE Transactions on, vol. 24, no. 3, pp. $714-724$, sept. 2009.

[13] Z. J. Zhou, X. Zhang, P. Xu, and W. Shen, "Single-phase uninterruptible power supply based on z-source inverter," Industrial Electronics, IEEE Transactions on, vol. 55, no. 8, pp. 2997 -3004, aug. 2008.

[14] F. Peng, X. Yuan, X. Fang, and Z. Qian, “Z-source inverter for adjustable speed drives," Power Electronics Letters, IEEE, vol. 1, no. 2, pp. 33 - 35, june 2003.

[15] C. Gajanayake, D. Vilathgamuwa, and P. C. Loh, "Development of a comprehensive model and a multiloop controller for z-source inverter dg systems," Industrial Electronics, IEEE Transactions on, vol. 54, no. 4, pp. $2352-2359$, aug. 2007.

[16] F. Z. Peng, M. Shen, and K. Holland, "Application of z-source inverter for traction drive of fuel cell battery hybrid electric vehicles," Power Electronics, IEEE Transactions on, vol. 22, no. 3, pp. $1054-1061$, may 2007.

[17] F. Gao, P. C. Loh, F. Blaabjerg, and D. Vilathgamuwa, "Dual z-source inverter with three-level reduced common-mode switching," Industry Applications, IEEE Transactions on, vol. 43, no. 6, pp. $1597-1608$, nov.-dec. 2007.

[18] P. C. Loh, F. Gao, F. Blaabjerg, S. Y. C. Feng, and K. N. J. Soon, "Pulsewidth-modulated z-source neutralpoint-clamped inverter," Industry Applications, IEEE Transactions on, vol. 43, no. 5, pp. 1295 -1308, sept.oct. 2007.

[19] P. C. Loh, F. Blaabjerg, and C. P. Wong, "Comparative evaluation of pulsewidth modulation strategies for Z-source neutral-point-clamped inverter," Power Electronics, IEEE Transactions on, vol. 22, no. 3, pp. $1005-1013$, may 2007.

[20] P. C. Loh, D. Vilathgamuwa, Y. Lai, G. T. Chua, and Y. Li, "Pulse-width modulation of z-source inverters," Power Electronics, IEEE Transactions on, vol. 20, no. 6, pp. $1346-1355$, nov. 2005.

[21] P. C. Loh, D. Vilathgamuwa, C. Gajanayake, Y. R. Lim, and C. W. Teo, "Transient modeling and analysis of pulse-width modulated z-source inverter," Power Electronics, IEEE Transactions on, vol. 22, no. 2, pp. 498 -507, march 2007.

[22] V. Blasko, "Analysis of a hybrid PWM based on modified space-vector and triangle-comparison methods," IEEE Trans. Ind. Appl., vol. 33, no. 3, pp. 756-764, May/June 1996.

[23] J. Liu, J. Hu, and L. Xu, "Dynamic modeling and analysis of z source converter - derivation of ac small signal model and design-oriented analysis," Power Electronics, IEEE Transactions on, vol. 22, no. 5, pp. $1786-1796$, sept. 2007.

[24] M. Shen and F. Z. Peng, "Operation modes and characteristics of the $z$-source inverter with small inductance or low power factor," Industrial Electronics, IEEE Transactions on, vol. 55, no. 1, pp. 89 -96, jan. 2008.

[25] X. Ding, Z. Qian, S. Yang, B. Cui, and F. Peng, "A pid control strategy for dc-link boost voltage in Z-source inverter," in Applied Power Electronics Conference, APEC 2007 - Twenty Second Annual IEEE, Mar. 2007, pp. $1145-1148$.

[26] Q.-V. Tran, T.-W. Chun, J.-R. Ahn, and H.-H. Lee, "Algorithms for controlling both the dc boost and ac output voltage of z-source inverter," Industrial 
Electronics, IEEE Transactions on, vol. 54, no. 5, pp. $2745-2750$, Oct. 2007.

[27] G. Sen and M. Elbuluk, "Voltage and currentprogrammed modes in control of the z-source converter," Industry Applications, IEEE Transactions on, vol. 46, no. 2, pp. $680-686$, march-april 2010.

[28] A. Rajaei, M. Mohamadian, S. Dehghan, and A. Yazdian, "Single-phase induction motor drive system using zsource inverter,' Electric Power Applications, IET, vol. 4, no. 1 , pp. $17-25$, january 2010.

[29] N. M. B. Abdel-Rahim and A. Shaltout, "An unsymmetrical two-phase induction motor drive with slip-frequency control," IEEE Trans. Energy Conversion, vol. 24, no. 3, pp. 608-616, Sept. 2009.

[30] M. Guerreiro, D. Foito, and A. Cordeiro, "A speed controller for a two-winding induction motor based on diametrical inversion," IEEE Trans. Ind. Electron., vol. 57, no. 1, pp. 449-456, Jan. 2010.

[31] M. A. Jabbar, A. M. Khambadkone, and Z. Yanfeng, "Space-vector modulation in a two-phase induction motor drive for constant-power operation," IEEE Trans. Ind. Electron., vol. 51, no. 5, pp. 1081-1088, Oct. 2004.

[32] G.-J. Su and J. S. Hsu, "A five-leg inverter for driving a traction motor and a compressor motor," IEEE Trans. Power Electron., vol. 21, no. 3, pp. 687-692, May 2006.

[33] E. dos Santos, M. Pacas, and M. Molina, "Two-phase motor drive systems with z-source inverter and hybrid pwm," in Energy Conversion Congress and Exposition (ECCE), 2010 IEEE, sept. 2010, pp. $3877-3882$.

[34] P. C. Loh, F. Gao, and F. Blaabjerg, "Embedded ez-source inverters," Industry Applications, IEEE Transactions on, vol. 46, no. 1, pp. 256 -267, jan.-feb. 2010.

[35] F. Gao, P. Loh, F. Blaabjerg, and C. Gajanayake, "Operational analysis and comparative evaluation of embedded z-source inverters," in Power Electronics Specialists Conference, 2008. PESC 2008. IEEE, june 2008, pp. $2757-2763$.

[36] C. Jacobina, E. dos Santos, E. da Silva, M. de Correa, A. Lima, and T. Oliveira, "Reduced switch count multiple three-phase ac machine drive systems," Power Electronics, IEEE Transactions on, vol. 23, no. 2, pp. 966 -976, march 2008.

[37] T. Kominami and Y. Fujimoto, "A novel nine-switch inverter for independent control of two three-phase loads," in Industry Applications Conference, 2007. 42nd IAS Annual Meeting. Conference Record of the 2007 IEEE, sept. 2007, pp. 2346-2350.

[38] S. Dehnavi, M. Mohamadian, A. Yazdian, and F. Ashrafzadeh, "Space vectors modulation for nine-switch converters," Power Electronics, IEEE Transactions on, vol. 25 , no. 6, pp. $1488-1496$, june 2010.

[39] S. Dehghan, M. Mohamadian, A. Yazdian, and F. Ashrafzadeh, "A dual-input-dual-output z-source inverter," Power Electronics, IEEE Transactions on, vol. 25 , no. 2, pp. $360-368$, feb. 2010.

[40] S. Dehghan, M. Mohamadian, and A. Yazdian, "Hybrid electric vehicle based on bidirectional z- source nine-switch inverter," Vehicular Technology, IEEE Transactions on, vol. 59, no. 6, pp. $2641-2653$, july 2010.

[41] M. Ashari, W. L. Keerthipala, and C. V. Nayar, "A single phase parallely connected uninterruptible power supply/demand side management system," IEEE Trans. Energy Conversion, vol. 15, no. 1, pp. 97-102, Mar. 2000.

[42] L. Woo-Cheol, L. Taeck-Kie, and H. Dong-Seok, "A three-phase parallel active power filter operating with PCC voltage compensation with consideration for an unbalanced load," IEEE Trans. Power Electron., vol. 17, no. 5, pp. 807-814, Sept. 2002.

[43] L. Asiminoaei, C. Lascu, F. Blaabjerg, and I. Boldea, "Performance improvement of shunt active power filter with dual parallel topology," IEEE Trans. Power Electron., vol. 22, no. 1, pp. 247-259, Jan 2007.

[44] L. Asiminoaei, E. Aeloiza, P. N. Enjeti, F. Blaabjerg, and G. Danfoss, "Shunt active-power-filter topology based on parallel interleaved inverters," IEEE Trans. Ind. Electron., vol. 55, no. 3, pp. 1175-1189, Mar. 2008.

[45] M. Pascual, G. Garcera, E. Figueres, and F. GonzalezEspin, "Robust model-following control of parallel UPS single-phase inverters," IEEE Trans. Ind. Electron., vol. 55, no. 8, pp. 2870-2883, Aug. 2008.

[46] J. Guerrero, J. Vasquez, J. Matas, M. Castilla, and L. de Vicuna, "Control strategy for flexible microgrid based on parallel line-interactive UPS systems," IEEE Trans. Ind. Electron., vol. 56, no. 3, pp. 726-736, Mar. 2009.

[47] P. Flannery and G. Venkataramanan, "A fault tolerant doubly fed induction generator wind turbine using a parallel grid side rectifier and series grid side converter," IEEE Trans. Power Electron., vol. 23, no. 3, pp. 11261135, May 2008.

[48] R. M. Cuzner, D. J. Nowak, A. Bendre, G. Oriti, and A. L. Julian, "Mitigating circulating common-mode currents between parallel soft-switched drive systems," IEEE Trans. Ind. Appl., vol. 43, no. 5, pp. 1284-1294, Sept./Oct. 2007.

[49] D. Vilathgamuwa, C. Gajanayake, and P. C. Loh, "Modulation and control of three-phase paralleled zsource inverters for distributed generation applications," Energy Conversion, IEEE Transactions on, vol. 24, no. 1, pp. $173-183$, march 2009.

[50] A. Nabae, I. Takahashi, and H. Akagi, "A new neutralpoint-clamped pwm inverter," Industry Applications, IEEE Transactions on, vol. IA-17, no. 5, pp. 518 -523, Sept. 1981.

[51] S. Mariethoz and A. Rufer, "New configurations for the three-phase asymmetrical multilevel inverter," in Industry Applications Conference, 2004. 39th IAS Annual Meeting. Conference Record of the 2004 IEEE, vol. 2, Oct. 2004, pp. $828-835$ vol.2.

[52] H. Weng, K. Chen, J. Zhang, R. Datta, X. Huang, L. Garces, R. Wagoner, A. Ritter, and P. Rotondo, "A four-level converter with optimized switching patterns for high-speed electric drives," in Power Electronics 
Specialists Conference, 2007. PESC 2007. IEEE, June 2007, pp. $1585-1591$.

[53] S. Kouro, M. Malinowski, K. Gopakumar, J. Pou, L. Franquelo, B. Wu, J. Rodriguez, M. Perez, and J. Leon, "Recent advances and industrial applications of multilevel converters," Industrial Electronics, IEEE Transactions on, vol. 57, no. 8, pp. 2553 -2580, Aug. 2010.

[54] P. Chan, H.-H. Chung, and S. Hui, "A generalized theory of boundary control for a single-phase multilevel inverter using second-order switching surface," Power Electronics, IEEE Transactions on, vol. 24, no. 10, pp. 2298 -2313, Oct. 2009.

[55] A. Boora, A. Nami, F. Zare, A. Ghosh, and F. Blaabjerg, "Voltage-sharing converter to supply singlephase asymmetrical four-level diode-clamped inverter with high power factor loads," Power Electronics, IEEE Transactions on, vol. 25, no. 10, pp. $2507-2520$, Oct. 2010.

[56] E. Villanueva, P. Correa, J. Rodriguez, and M. Pacas, "Control of a single-phase cascaded h-bridge multilevel inverter for grid-connected photovoltaic systems," Industrial Electronics, IEEE Transactions on, vol. 56, no. 11, pp. $4399-4406$, Nov. 2009.

[57] E. Ozdemir, S. Ozdemir, and L. Tolbert, "Fundamentalfrequency-modulated six-level diode-clamped multilevel inverter for three-phase stand-alone photovoltaic system," Industrial Electronics, IEEE Transactions on, vol. 56, no. 11, pp. $4407-4415$, Nov. 2009.

[58] A. Nami, F. Zare, A. Ghosh, and F. Blaabjerg, "A hybrid cascade converter topology with series-connected symmetrical and asymmetrical diode-clamped h-bridge cells," Power Electronics, IEEE Transactions on, vol. 26, no. 1, pp. $51-65$, Jan. 2011.

[59] P. Loh, F. Blaabjerg, S. Feng, and K. Soon, "Pulse-width modulated z-source neutral-point-clamped inverter," in Applied Power Electronics Conference and Exposition, 2006. APEC '06. Twenty-First Annual IEEE, march 2006, p. 7 pp.

[60] P. C. Loh, D. M. Vilathgamuwa, C. J. Gajanayake, L. T. Wong, and C. P. Ang, "Z-source current-type inverters: Digital modulation and logic implementation," Power Electronics, IEEE Transactions on, vol. 22, no. 1, pp. 169 -177 , jan. 2007.

[61] P. C. Loh, S. W. Lim, F. Gao, and F. Blaabjerg, "Threelevel z-source inverters using a single lc impedance network," Power Electronics, IEEE Transactions on, vol. 22, no. 2, pp. 706-711, march 2007.

[62] P. C. Loh, F. Gao, and F. Blaabjerg, "Topological and modulation design of three-level z-source inverters," Power Electronics, IEEE Transactions on, vol. 23, no. 5, pp. $2268-2277$, sept. 2008.

[63] P. C. Loh, F. Gao, P.-C. Tan, and F. Blaabjerg, "Three-level ac-dc-ac z-source converter using reduced passive component count," Power Electronics, IEEE Transactions on, vol. 24, no. 7, pp. $1671-1681$, july 2009.

[64] F. Gao, P. Loh, F. Blaabjerg, R. Teodorescu, and
D. Vilathgamuwa, "Five-level z-source diode-clamped inverter," Power Electronics, IET, vol. 3, no. 4, pp. 500 -510 , july 2010.

[65] M. Banaei and A. Dehghanzadeh, "Dvr based cascaded multilevel z-source inverter," in Power and Energy (PECon), 2010 IEEE International Conference on, Dec. 2010 , pp. $51-56$.

[66] J. Anderson and F. Peng, "A class of quasi-z-source inverters," in Industry Applications Society Annual Meeting, 2008. IAS '08. IEEE, oct. 2008, pp. 1 -7.

[67] M. Zhu, K. Yu, and F. L. Luo, "Switched inductor zsource inverter," Power Electronics, IEEE Transactions on, vol. 25, no. 8, pp. $2150-2158$, aug. 2010.

[68] M. Zhu, D. Li, P. C. Loh, and F. Blaabjerg, "Tappedinductor z-source inverters with enhanced voltage boost inversion abilities," in Sustainable Energy Technologies (ICSET), 2010 IEEE International Conference on, dec. 2010, pp. $1-6$.

[69] C. Gajanayake, F. L. Luo, H. B. Gooi, P. L. So, and L. K. Siow, "Extended-boost $z$-source inverters," Power Electronics, IEEE Transactions on, vol. 25, no. 10, pp. 2642 -2652, oct. 2010.

[70] X. P. Fang, Z. M. Qian, and F. Z. Peng, "Single-phase zsource pwm ac-ac converters," Power Electronics Letters, IEEE, vol. 3, no. 4, pp. 121 - 124, dec. 2005.

[71] M.-K. Nguyen, Y.-G. Jung, and Y.-C. Lim, "Single-phase ac-ac converter based on quasi-z-source topology," Power Electronics, IEEE Transactions on, vol. 25, no. 8, pp. $2200-2210$, aug. 2010.

[72] Y. Tang, S. Xie, and C. Zhang, "Z-source ac-ac converters solving commutation problem," Power Electronics, IEEE Transactions on, vol. 22, no. 6, pp. 2146 -2154, nov. 2007.

[73] K. Park and K.-B. Lee, "A novel sparse matrix converter with a z-source network," in Industrial Electronics, 2009. IECON '09. 35th Annual Conference of IEEE, nov. 2009, pp. $4487-4492$.

[74] K. Park, S.-T. Jou, and K.-B. Lee, "Z-source matrix converter with unity voltage transfer ratio," in Industrial Electronics, 2009. IECON '09. 35th Annual Conference of IEEE, nov. 2009, pp. $4523-4528$.

[75] K. You and M. Rahman, "A new power converter for isa $42 \mathrm{v}$ powernet system using matrix converter theory and z-source inverter concepts," in Vehicle Power and Propulsion, 2005 IEEE Conference, sept. 2005, p. 7 pp.

[76] K. You and M. F. Rahman, "A matrix-source converter with ac-dc bidirectional power flow for an integrated starter alternator system," Industry Applications, IEEE Transactions on, vol. 45, no. 1, pp. 239-248, Jan. 2009.

[77] K. You and F. Rahman, "Modulation and control schemes for a new power converter based on z-source and matrix converter for isa $42 \mathrm{v}$ powernet system," in Power Electronics and Drives Systems, 2005. PEDS 2005. International Conference on, vol. 1, 0-0 2005, pp. 436 -441 .

[78] K. You and M. F. Rahman, "Analytical comparison of conduction and switching losses of a novel matrix-zsource converter and a conventional vsi converter for 
automotive isa $42 \mathrm{v}$ system," in Proc. IEEE PESC, 2006, pp. 1-7.

[79] K. You and F. Rahman, "Over-voltage protection using power zener diode for matrix converter and matrixz-source converter," in Power Electronics and Drive Systems, 2009. PEDS 2009. International Conference on, nov. 2009, pp. $193-197$.

[80] F. Z. Peng, "Z-source networks for power conversion," in Applied Power Electronics Conference and Exposition, 2008. APEC '08. Twenty-First Annual IEEE, march 2008, pp. $1258-1265$.

[81] F. Peng, "Revisit power conversion circuit topologiesrecent advances and applications," in Power Electronics and Motion Control Conference, 2009. IPEMC '09. IEEE 6th International, may 2009, pp. $188-192$.

[82] — " "Recent advances and applications of power electronics and motor drives - power converters," in Industrial Electronics, 2008. IECON 2008. 34th Annual Conference of IEEE, nov. 2008, pp. 30 -33.

[83] K. Park, E.-S. Lee, and K.-B. Lee, “A z-source sparse matrix converter with a fuzzy logic controller based compensation method under abnormal input voltage conditions," in Industrial Electronics (ISIE), 2010 IEEE International Symposium on, july 2010, pp. 614-619.

[84] K. Park and K.-B. Lee, "A z-source sparse matrix converter under a voltage sag condition," in Energy Conversion Congress and Exposition (ECCE), 2010 IEEE, sept. 2010, pp. $2893-2898$.

[85] X. Liu, P. C. Loh, F. Z. Peng, and P. Wang, "Optimal modulation of indirect Z-source matrix converter," in Power Electronics Conference (IPEC), 2010 International, june 2010, pp. 3049 -3056.

[86] X. Liu, P. C. Loh, F. Z. Peng, P. Wang, and F. Gao, "Modulation of three-level z-source indirect matrix converter," in Energy Conversion Congress and Exposition (ECCE), 2010 IEEE, sept. 2010, pp. 3195 3201.

\section{BIOGRAPHIES}

Euzeli C. dos Santos Jr. received the B.S., M.S., and Ph.D. degrees in Electrical Engineering from the Federal University of Campina Grande, Campina Grande, Brazil, in 2004, 2005, and 2007, respectively. From 2006 to 2007, he was with Electric Machines and Power Electronics Laboratory, Texas A\&M University, College Station, as a Visiting Scholar. From December 2010 to March 2011 he was a visiting professor at the University of Siegen, Germany. From March 2009 to June 2012, he was with the Department of Electrical Engineering, Federal University of Campina Grande, as a professor of electrical engineering. Since July 2012 he has been with the Indiana University-Purdue University Indianapolis (IUPUI), where he is now a professor of electrical engineering. His research interests include power electronics, electrical drives and renewable energy systems.

Fabrício Bradaschia was born in São Paulo, Brazil, in 1983. He received the B.Sc., M.Sc. and Ph.D. degrees in electrical engineering from the Federal University of Pernambuco, Recife, Brazil, in 2006, 2008 and 2012, respectively. From August 2008 to August 2009, he worked as a Visiting Scholar at the University of Alcalá, Madrid, Spain. Since 2012, he is working as a substitute professor in the Department of Electrical Engineering at the Federal University of Pernambuco. His research interests are Z-source converters, renewable energy systems and grid synchronization methods.

Marcelo C. Cavalcanti was born in Recife, Brazil, in 1972. He received the B.Sc. degree in electrical engineering in 1997 from the Federal University of Pernambuco, Recife, Brazil, and the M.Sc. and Ph.D. degrees in electrical engineering from the Federal University of Campina Grande, Campina Grande, Brazil, in 1999 and 2003, respectively. He worked as a visiting scholar at Center for Power Electronics Systems, Virginia Polytechnic Institute and State University, Blacksburg, USA, from October 2001 to August 2002. Since 2003, he has been at the Department of Electrical Engineering, Federal University of Pernambuco, where he is currently a Professor of Electrical Engineering. His research interests are renewable systems and power quality.

Edison R. C. da Silva was born in Pelotas, Brazil, in 1942. He received the B.C.E.E. degree from the Polytechnic School of Pernambuco, Recife, Brazil, the M.S.E.E. degree from the University of Rio de Janeiro, Brazil, and the Dr. Eng. degree from the University Paul Sabatier, Toulouse, France, in 1965, 1968, and 1972, respectively. From 1967 to March 2002 he was with the Electrical Engineering Department of Federal University of Paraiba. Since April 2002, he has been with the Electrical Engineering Department of Federal University of Campina Grande, Campina Grande, Paraiba, Brazil, where he is a Professor of Electrical Engineering and Director of the Research Laboratory on Industrial Electronics and Machine Drives. In 1990 he was with COPPE, Federal University of Rio de Janeiro, and from 1990 to 1991, he was with WEMPEC, University of Wisconsin, Madison, as a Visiting Professor. His current research work is in the area of power electronics and motor drives. Dr. Da Silva was the General Chairman of the 1984 Joint Brazilian and Latin-American Conference on Automatic Control, sponsored by the Automatic Control Brazilian Society and was the General Chairman of The IEEE Power Electronics Specialists Conference, PESC'05. 